\title{
Three FLOWERING LOCUS T-like genes function as potential florigens and mediate photoperiod response in sorghum
}

\author{
Tezera W. Wolabu ${ }^{1}$, Fei Zhang ${ }^{1}$, Lifang Niu ${ }^{1,2}$, Shweta Kalve ${ }^{1}$, Pooja Bhatnagar-Mathur ${ }^{3}$, Michael G. Muszynski ${ }^{4}$ \\ and Million Tadege ${ }^{1}$ \\ ${ }^{1}$ Department of Plant and Soil Sciences, Institute for Agricultural Biosciences, Oklahoma State University, 3210 Sam Noble Parkway, Ardmore, OK 73401 , USA; ${ }^{2}$ Biotechnology Research \\ Institute, Chinese Academy of Agricultural Sciences, Beijing 100081, China; ${ }^{3}$ International Crops Research Institute for the Semi-Arid Tropics (ICRISAT), Patancheru, Telangana 502324, \\ India; ${ }^{4}$ Department of Genetics, Development and Cell Biology, Iowa State University, 2156 Molecular Biology, Ames, IA 50011, USA
}

Author for correspondence: Million Tadege

Tel: +15802240629

Email: million.tadege@okstate.edu

Received: 22 July 2015

Accepted: 30 November 2015

New Phytologist (2016)

doi: $10.1111 /$ nph.13834

Key words: florigen, flowering time, FT, photoperiod response, SbFT, Sb14-3-3, SbFD1, Sorghum bicolor.

\section{Summary}

- Sorghum is a typical short-day (SD) plant and its use in grain or biomass production in temperate regions depends on its flowering time control, but the underlying molecular mechanism of floral transition in sorghum is poorly understood.

- Here we characterized sorghum FLOWERING LOCUST (SbFT) genes to establish a molecular road map for mechanistic understanding. Out of 19 PEBP genes, SbFT1, SbFT8 and SbFT10 were identified as potential candidates for encoding florigens using multiple approaches.

- Phylogenetic analysis revealed that SbFT1 clusters with the rice Hd3a subclade, while SbFT8 and SbFT10 cluster with the maize ZCN8 subclade. These three genes are expressed in the leaf at the floral transition initiation stage, expressed early in grain sorghum genotypes but late in sweet and forage sorghum genotypes, induced by SD treatment in photoperiod-sensitive genotypes, cooperatively repressed by the classical sorghum maturity loci, interact with sorghum 14-3-3 proteins and activate flowering in transgenic Arabidopsis plants, suggesting florigenic potential in sorghum.

- SD induction of these three genes in sensitive genotypes is fully reversed by $1 \mathrm{wk}$ of longday treatment, and yet, some aspects of the SD treatment may still make a small contribution to flowering in long days, indicating a complex photoperiod response mediated by SbFT genes.

\section{Introduction}

Floral transition is a major phase change in flowering plants where developmental programs switch from vegetative growth to reproductive growth in which gametes are formed to ensure continuity to the next generation. Thus, plants coordinate the timing of their flowering with environmental changes to achieve reproductive success. Several environmental factors and endogenous developmental signals converge to determine reproductive competence and flowering. At the heart of this competence is a flowering hormone called florigen, originally proposed by Chailakhyan c. $80 \mathrm{yr}$ ago (Chailakhyan, 1936). Florigen is a leaf-derived, grafttransmissible signal that under inductive conditions moves from the leaf to the shoot apex through the phloem to induce transition to the reproductive phase (Chailakhyan, 1936, 1937; Zeevaart, 1976). The long-sought-after florigen has now been widely accepted to be the protein encoded by the FLOWERING LOCUS $T$ (FT) gene of Arabidopsis and its orthologs (Lifschitz et al., 2006; Corbesier etal., 2007; Jaeger \& Wigge, 2007; Tamaki et al., 2007; Giakountis \& Coupland, 2008; Zeevaart, 2008). FT encodes a protein with similarity to the mammalian phosphatidylethanolamine binding protein (PEBP) (Kardailsky et al., 1999; Kobayashi et al., 1999). Under long-day (LD) conditions, Arabidopsis FT is up-regulated in the leaf by CONSTANS (CO) (Samach et al., 2000), which encodes a B-box zinc finger transcription factor with a CCT domain (Putterill et al., 1995). $C O$ is diurnally regulated by photoreceptors and the circadian clock, and its protein accumulates towards the end of day in LDs but is degraded in short days (SDs) (Suárez-López et al., 2001; Valverde et al., 2004). In response to CO accumulation at dusk, FT transcript abundance peaks at the end of day in LDs but not in SDs (Kardailsky et al., 1999; Suárez-López et al., 2001). The FT protein is then transported from the leaf through the vasculature to the shoot apex (Corbesier et al., 2007; Jaeger \& Wigge, 2007; Lin et al., 2007; Mathieu et al., 2007), where it forms a complex with FLOWERING LOCUS D (FD) to activate floral transition (Abe et al., 2005; Wigge et al., 2005). FD is a bZIP transcription factor that in complex with FT activates the transcription of floral meristem identity genes such as APETALA1 (AP1) and LEAFY (LFY). FT homologs have been reported from several species of both dicots and monocots with LD, SD or dayneutral requirements for floral induction. 
In the SD plant rice, Heading date $3 a(H d 3 a)$, the ortholog of $F T$, is activated by Heading date 1 ( $H d 1$ ), the ortholog of $C O$, in SD photoperiods to induce flowering (Kojima et al., 2002) analogous to the CO-FT activity in Arabidopsis. A second florigen, Rice flowering locus T1 (RFT1), has also been identified to promote flowering under LD conditions (Komiya et al., 2008). Rice indeterminate 1 (RID1), also called $O s I D 1$ or Ehd2, a C2H zinc finger transcription factor homologous to the maize ID1 (Colasanti et al., 1998) gene, promotes flowering by activating Early heading date1 (Ehd 1 ) independent of day length (Matsubara et al., 2008; Park et al., 2008; Wu et al., 2008). Ehd1 is a B-type response regulator induced by SD photoperiods and promotes flowering by activating $H d 3 a / F T$-like genes independent of $H d 1$ (Doi et al., 2004). On the other hand, Grain number, plant height and heading date7 (Ghd7) (Xue et al., 2008), encoding a CCT domain protein homologous to wheat VRN2 (Yan et al., 2004), represses flowering in LDs by down-regulating Ehd1 and Hd 3 a (Itoh et al., 2010). Thus, the promoter and repressor activities of Ehd1 and Ghd7, respectively, enable the control of Hd3a transcription with a critical day-length threshold in rice to a resolution of $30 \mathrm{~min}$ (Itoh et al., 2010). The proteins of both Hd3a and RFT1 are shown to move to the shoot apex (Tamaki et al., 2007; Komiya et al., 2009). In the shoot apex, 14-3-3 proteins bind to $\mathrm{Hd} 3 \mathrm{a}$ as intracellular receptors, and the resulting complex is translocated to the nucleus to bind to OsFD1, homolog of FD, forming a ternary florigen activation complex (FAC), which induces transcription of OsMADS15, a homolog of $A P 1$, leading to flowering (Taoka et al., 2011).

In maize, INDETERMINATE1 (ID1), a $\mathrm{C} 2 \mathrm{H} 2$ zinc finger transcription factor, and DELAYED FLOWERING1 (DLF1), a homolog of FD, activate flowering in the leaf and shoot apex, respectively (Colasanti etal., 1998; Muszynski et al., 2006). $Z M M 4$, a homolog of $A P 1$, promotes flowering downstream of $D L F 1$ in the shoot apex (Danilevskaya et al., 2008a). Out of 25 FT-like genes, ZCN8 (Zea mays CENTRORADIALIS 8) has been identified as the best maize florigen candidate activating flowering (Danilevskaya et al., 2008b; Lazakis et al., 2011; Meng et al., 2011). ZCN8 is diurnally regulated and its transcript is induced after $7 \mathrm{~d}$ exposure to SD conditions in tropical maize but photoperiod sensitivity is attenuated in day-neutral temperate maize, activating flowering independent of day length (Danilevskaya et al., 2011). ZCN8 functions downstream of IDI and upstream of DLF1 and ZMM4, analogous to the rice flowering pathway.

In sorghum (Sorghum bicolor), flowering time is a key agronomic trait that determines whether it can be used as a grain or biomass crop. Sorghum is a multipurpose crop grown in many parts of the world, especially in arid and semiarid regions for food, feed, fuel and fiber. Sorghum is a typical SD plant with substantial photoperiod sensitivity. However, like maize, photoperiod-insensitive genotypes have been selected by breeders for grain production in temperate regions. As a result, temperate sorghum can be classified as grain sorghum with attenuated photoperiod response, biomass sorghum (includes forage and energy sorghum) and sweet sorghum. Biomass and sweet sorghums require a SD photoperiod for early flowering and flower very late under LD conditions, and were selected for increased biomass yield through longer duration of vegetative growth in temperate regions (Rooney etal., 2007; Olson et al., 2012). Grain sorghums, on the other hand, were selected for early flowering irrespective of day length to optimize grain yield production.

Despite this critical importance of flowering time for sorghum agronomy and the existence of $>40$ flowering time quantitative trait loci (Mace etal., 2013), very little is known about the molecular mechanism of flowering time control in sorghum. Six maturity loci (named Mal-MaO) that modify photoperiod sensitivity have been identified by genetic analysis (Quinby \& Karper, 1945; Quinby, 1966; Rooney \& Aydin, 1999; Morgan \& Finlayson, 2000) in which dominance at each locus delays flowering under LD conditions. Mal was identified as SbPRR37, a pseudoresponse regulator ortholog of rice OsPRR37 (Koo et al., 2013) and barley Ppd-H1 (Turner et al., 2005) which represses flowering under LD conditions (Murphy et al., 2011). Ma3 encodes phytochrome B (Childs et al., 1997), while Ma 6 corresponds to SbGhd7 (Murphy et al., 2014), ortholog of the rice floral repressor Ghd7. Thus SbPRR37, SbPhyB and SbGhd7 are floral repressors and confer photoperiod sensitivity upstream of the floral activators, ortholog of Ehd1 and FT-like genes SbCN8 and SbCN12 (Murphy et al., 2011; Yang et al., 2014b).

Here we cloned and characterized 13 FT-like genes from sorghum to establish a molecular road map for understanding the mechanism of flowering time control in sorghum. With comprehensive analysis of spatial and temporal expression pattern, genotype-specific expression patterns including commonly used cultivars and natural mutants, photoperiod response, proteinprotein interaction patterns and transgenic analysis, we identified that out of 19 PEBP genes in the sorghum genome, three genes, designated here as SbFT1, SbFT8 and SbFT10, behave as functional Hd3a/RFT1/ZCN8 orthologs, suggesting that sorghum probably has three florigens. We show that the three $S b F T$ genes are induced by $1 \mathrm{wk} S D$ treatment in photoperiod-sensitive genotypes and mediate photoperiod response, but the SD induction can be reversed by transition to LDs.

\section{Materials and Methods}

\section{Plant materials and growth conditions}

Sorghum bicolor (L.) Moench genotypes; grain sorghum (BTx623 and Tx430), sweet sorghum (Theis and Rio) and forage sorghum (FS000504 and FS000991) with wide differences in photoperiod response and flowering time were grown in 1 gallon pots in the glasshouse under LD conditions with a $16: 8 \mathrm{~h}$, light : dark cycle and a temperature of $27-30^{\circ} \mathrm{C}$, and in the growth chamber under $\mathrm{SD}$ conditions with an $8: 16 \mathrm{~h}$, light : dark cycle and a temperature of $24-27^{\circ} \mathrm{C}$ with $70-80 \%$ relative humidity and $150 \mu \mathrm{mol} \mathrm{m}{ }^{2}$ light intensity. In addition, early-flowering mutants of sorghum, 38M $\left(m a, m a 2, m a 3^{R}\right), 44 \mathrm{M}\left(m a 2, m a 3^{R}\right), 90 \mathrm{M}$ (ma3) and the control 100M (Ma1, Ma2, Ma3, Ma4) were grown under LD conditions in the glasshouse. Arabidopsis plants, Landsberg erecta (Ler) ecotype and $f t-1$ mutant were grown in the growth room under LD conditions with a $16: 8 \mathrm{~h}$, light : dark cycle at $23-25^{\circ} \mathrm{C}$. 


\section{Plant tissue sample collection}

The developmental stages of sorghum in relation to timing of morphological changes during the course of plant development have been well described (Vanderlip \& Reeves, 1972). Six growth stages (S0-S6) were selected to collect samples for transcript analyses. S0 represents seedling emergence, where coleoptile is just visible; $\mathrm{S} 1$ is $10 \mathrm{~d}$ after emergence when the collar of the third leaf is visible; S2 is when the collar of the fifth leaf is visible $20 \mathrm{~d}$ after emergence; $\mathrm{S} 3$ is the growing point differentiation with seven to 10 leaf collars c. $30 \mathrm{~d}$ after emergence; $\mathrm{S} 5$ is booting stage at $50 \mathrm{~d}$ after emergence where the head is extended into the flag leaf sheath; and S6 is the half blooming (anthesis) stage at $60 \mathrm{~d}$ after emergence (Vanderlip \& Reeves, 1972). Five samples were collected and pooled from fully expanded top leaves or other tissues as specified.

For diurnal expression analysis, young, fully expanded leaf samples were harvested from three randomly selected BTх623 plants every $4 \mathrm{~h}$ during $52 \mathrm{~h}$ in the $24 \mathrm{~h}$ diurnal cycle. Samples were analyzed by real time quantitative reverse transcription polymerase chain reaction (qRT-PCR) using actin as control. Leaf samples from grain, sweet and forage sorghum genotype were also collected separately for varietal-based analysis of $S b F T$ transcript abundance. Samples were collected after midnight when the highest transcript accumulation of SbFT genes was found. Collected samples were immediately snap-frozen in liquid nitrogen and stored at $-80^{\circ} \mathrm{C}$ until processing.

\section{RNA extraction, gene cloning and transformation}

Total RNA was isolated using TRIzol Reagent (Invitrogen) for cDNA synthesis. Reverse transcription was performed using RNA treated with DNase I (Invitrogen), an oligo(dT) primer and SuperScript III reverse transcriptase (Invitrogen) according to the manufacturer's instructions. Expression pattern analyses were performed using semiquantitative RT-PCR. Full-length SbFT1, SbFT2, SbFT6, SbFT8, SbFT9 and SbFT10 coding sequences were amplified by RT-PCR using total RNA extracted from leaf and apex tissues. Cloning was performed in the pMDC32 gateway destination vector with $2 \times 35 S$ promoter for SbFT1 and SbFT8, while leaf-specific STF promoter (Tadege et al., 2011) was used for the SbFT10 construct and the resulting plasmids were transformed into Agrobacterium tumefaciens strain GV3101 by the freeze-heat shock method. Arabidopsis was transformed using the floral dipping method (Clough \& Bent, 1998).

\section{Multiple sequence alignment and phylogenetic analysis}

Multiple sequence alignment of 19 PEBP proteins of sorghum and homologs from other related species was performed using BioEdit software and the ClustalW program (http:// www.mbio.ncsu.edu/bioedit/bioedit.html). A neighbor-joining phylogenic tree was constructed using MEGA6.0 default settings with 1000 bootstrap replications (http://www. megasoftware.net/ ). All gene sequences used in this study were listed as Supporting Information Notes $S 1$.

\section{Yeast two-hybrid ( $\mathrm{Y} 2 \mathrm{H})$ assays}

Yeast two-hybrid analysis was performed using the ProQuest Two-Hybrid system (Invitrogen) following the manufacturer's instructions. The full-length proteins of AtFD and SbFD1 were cloned in pGBKT7-GW as bait, while the full-length proteins of SbFT1, SbFT8 and SbFT10 were cloned in pGADT7-GW as prey, and sets of constructs were cotransformed into $\mathrm{Y} 2 \mathrm{H}$ Gold yeast strain (Clontech, Mountain View, CA, USA). Yeast transformants were selected on synthetic minimal double dropout medium deficient in $S D /-L e u /$-Trp , and protein interactions were assessed on quadruple dropout medium deficient in SD/-His/Trpl-Leul-Ade.

\section{Bimolecular florescence (BiFC) analysis and confocal microscopy}

Bimolecular florescence assays were conducted according to $\mathrm{Lu}$ et al. (2010). Briefly, SbFT1, SbFT8 and SbF10 were cloned into pEARLEYGATE201-YN, while AtFD and Sb14-3-3 were cloned into pEARLEYGATE202-YC, by LR reaction. For the SbFD1 BiFC assay, SbFT1, SbFT8, SbF10 and Sb14-3-3 were cloned into pEARLEYGATE202-YC, while SbFD1 was cloned into pEARLEYGATE201-YN. Each construct was introduced into Agrobacterium by the freeze-heat shock method. Pairs of combinations were coinfiltrated into 4-wk-old Nicotiana benthamiana leaves. P19 was used to inhibit transgenic silencing. The yellow fluorescent protein (YFP) signal was observed after 48-60 h of infiltration using a TCS SP2 AOBS confocal laser scanning microscope (Leica Microsystems, Buffalo Grove, IL, USA).

\section{Results}

Multiple sequence alignment and phylogenetic analysis of sorghum FT/TFL1/MFT-Like proteins with homologs from other related species

BLAST search of the S. bicolor genome v2.1 using Arabidopsis FT and rice $H d 3 a$ sequences identified 19 phosphatidylethanolamine binding protein (PEBP) family genes showing significant homology to both $F T$ and $H d 3 a$ at the DNA and amino acid sequence level. Of these 19 PEBP sequences, 13 are FLOWERING LOCUS T (FT)-like, four are TERMINAL FLOWER LIKE1 (TFL1)-like and two are MOTHER OF FT and TFL1 (MFT)like. On the basis of sequence homology to $H d 3 a$, we designated the 13 FT-like genes SbFT1 to SbFT13, the four TFL1-like genes SbTFL1-1 to SbTFL1-4 and the two MFT-like genes SbMFT1 and SbMFT2 (Table 1). SbFT1, SbFT8 and SbFT10 correspond to $\mathrm{SbCN} 15$, SbCN12 and SbCN8, respectively, reported in previous studies (Yang et al., 2014a,b). The 19 sorghum PEBP genes show limited homology to each other (Table S1), but have close homologs in both the maize and rice genomes (Table S2). The conserved PEBP domain displayed very high homology among sorghum PEBPs and FT-like genes from other species (Fig. S1) in which the functionally important tyrosine $(\mathrm{Y})$ at position 87 in SbFT1 was conserved in all FT-like proteins but substituted by a 
Table 1 Summary of 19 sorghum PEBP genes compared with FT genes from Arabidopsis, maize, rice and wheat

\begin{tabular}{|c|c|c|c|c|c|c|c|c|c|}
\hline \multirow{2}{*}{\multicolumn{2}{|c|}{ Designation }} & \multirow{3}{*}{$\begin{array}{l}\text { Alias name } \\
\text { (Sb10g003940) }\end{array}$} & \multirow{3}{*}{$\begin{array}{l}\text { Protein size } \\
179\end{array}$} & \multicolumn{6}{|c|}{ Full-length amino acid identity (\%) } \\
\hline & & & & \multirow{2}{*}{$\begin{array}{l}\text { AtFT } \\
72\end{array}$} & \multirow{2}{*}{$\frac{Z C N 8}{62}$} & \multirow{2}{*}{$\frac{\text { ZCN12 }}{65}$} & \multirow{2}{*}{$\begin{array}{l}\text { ZCN15 } \\
97\end{array}$} & \multirow{2}{*}{$\frac{H d 3 a}{93}$} & \multirow{2}{*}{$\frac{V R N 3}{92}$} \\
\hline 1 & SbFT1 & & & & & & & & \\
\hline 2 & SbFT2 & (Sb03g001700) & 173 & 72 & 58 & 60 & 82 & 79 & 82 \\
\hline 3 & SbFT3 & (Sb06g020850) & 174 & 73 & 56 & 57 & 70 & 70 & 71 \\
\hline 4 & SbFT4 & (Sb04g025210) & 174 & 70 & 57 & 56 & 69 & 68 & 70 \\
\hline 5 & SbFT5 & (Sb0010s003120) & 177 & 70 & 57 & 57 & 70 & 70 & 71 \\
\hline 6 & SbFT6 & (Sb02g029725) & 178 & 67 & 52 & 54 & 62 & 63 & 61 \\
\hline 7 & SbFT7 & (Sb04g008320) & 182 & 63 & 58 & 62 & 64 & 64 & 65 \\
\hline 8 & SbFT8 & (Sb03g034580) & 177 & 59 & 79 & 94 & 65 & 64 & 64 \\
\hline 9 & SbFT9 & (Sb10g021790) & 173 & 62 & 59 & 60 & 63 & 62 & 62 \\
\hline 10 & SbFT10 & (Sb09g025760) & 175 & 53 & 97 & 83 & 66 & 69 & 66 \\
\hline 11 & SbFT11 & (Sb08g008180) & 177 & 62 & 51 & 51 & 62 & 60 & 62 \\
\hline 12 & SbFT12 & (Sb06g012260) & 185 & 58 & 57 & 59 & 59 & 59 & 61 \\
\hline 13 & SbFT13 & (Sb03g002500) & 187 & 61 & 55 & 56 & 63 & 62 & 62 \\
\hline 14 & SbTFL1-1 & (Sb04g021650) & 173 & 56 & 49 & 53 & 58 & 60 & 58 \\
\hline 15 & SbTFL1-2 & (Sb08g003210) & 173 & 43 & 39 & 57 & 50 & 62 & 61 \\
\hline 16 & SbTFL1-3 & (Sb05g003200) & 173 & 54 & 47 & 55 & 63 & 60 & 59 \\
\hline 17 & SbTFL1-4 & (Sb06g015490) & 173 & 54 & 51 & 53 & 60 & 60 & 60 \\
\hline 18 & SbMFT1 & (Sb03g008270) & 171 & 57 & 46 & 47 & 55 & 57 & 56 \\
\hline 19 & SbMFT2 & (Sb10g013070) & 181 & 43 & 37 & 39 & 37 & 50 & 51 \\
\hline
\end{tabular}

conserved histidine $(\mathrm{H})$ residue (Hanzawa et al., 2005) in TFL1-like proteins (Figs 1a, S1). Among the 13 SbFT proteins, only SbFT5 had an asparagine (N) substitution at the equivalent position (Fig. 1a). This position also appeared not to be conserved in MFT-like proteins (Fig. 1a).

Phylogenetic analysis revealed that sorghum PEBPs are grouped into three major clades: the FT clade containing SbFT1 to SbFT13, the TFL1 clade containing SbTFL1-1 to SbTFL1-4, and the MFT clade containing SbMFT1 and SbMFT2 (Fig. 1b). The FT clade could be further subdivided into three groups. The functionally characterized monocot florigens, except maize ZCN8, clustered together in the Hd3a subclade. SbFT1 and SbFT2 belong to this group. The second subgroup, represented by AtFT, included SbFT3-6 and SbFT11. The third subgroup represented by ZCN8, included SbFT7-10, 12 and 13 (Fig. 1b). As AtFT, Hd3a and ZCN8 are well characterized major components of the FAC and the SbFT genes are distributed in all of these three subclades, it is not a trivial task to determine which of these SbFT genes function as activators of floral transition in sorghum.

Three sorghum FT genes are highly expressed in grain sorghum leaves at the floral transition stage

To understand which sorghum FT-like genes play functional roles in regulating flowering time, we assessed the temporal and spatial expression patterns of the 19 PEBP genes in different tissues at different developmental stages in grain sorghum BTx623 genotype grown under LD conditions. The developmental stages of grain sorghum in relation to timing of morphological changes have been well described (Vanderlip \& Reeves, 1972). We selected six growth stages (S0-S6) to collect samples for transcript analyses (see the Materials and Methods section). Expression analysis in different tissues by semiquantitative RT-PCR using gene- specific primers (Table S3) revealed that most SbFT/TFL1-like genes were expressed amongst many of the different tissues tested (Fig. 2a). SbFT3, SbFT4 and all the four SbTFL1-like gene transcripts were detected in roots at variable expression levels. SbFT1, SbFT3, SbFT6, SbFT8, SbFT9 and SbFT10 genes were variably expressed in leaf from seedling stage (S0) to transition stage (S3). Of these six genes, five (SbFT1, SbFT6, SbFT8, SbFT9 and $S b F T 10)$ showed strong transcript accumulation during the critical floral transition period (S3). However, SbFT6 and SbFT9 also showed strong expression in the leaf at earlier developmental stages (S0-S2), leaving SbFT1, SbFT8 and SbFT10 as the only candidates that were specifically and strongly induced near the floral transition stage (Fig. 2a). Expression of SbFT1 and SbFT3 in the shoot apex at stage $\mathrm{S} 3$ was very weak but $S b F T 2,4,5,9,11$ and all of SbTFL1s, except SbTFL1-4, were strongly expressed in the shoot apex (Fig. 2a). On the other hand, SbFT2, SbTFL1-1 and SbTFL1-3 were detected in the stem at variable levels. SbTFL1-4 was only very weakly expressed in root and shoot apex. SbFT1, SbFT2, SbFT6, SbFT8, SbFT10, SbFT11, SbTFL1-1 and SbTFL1-2 transcripts were also detected in the floral head at booting (S5) and in florets at blooming (S6) stages at various levels (Fig. 2a). The remaining five genes, SbFT7, SbFT12, SbFT13, SbMFT1 and SbMFT2, were not detectable in the tissues analyzed. The strong and specific transcript accumulation of $S b F T 1$, SbFT8 and SbFT10 in the leaf near the time of the critical floral transition period suggests that these three genes could be the sources of sorghum florigen, although this does not exclude the possibility that others may also have a contribution. For this reason, we focused on the three genes, SbFT1, SbFT8 and SbFT10, to further characterize their involvement in flowering.

To determine if sorghum FT gene expression follows diurnal cycling, we assessed the diurnal expression patterns of $S b F T 1$, SbFT8 and SbFT10 in grain sorghum BTx623 under LD conditions using real-time qRT-PCR. Our results indicated that 
(a)

SbETI

SbET2

SBET 3

SBET 4

SBET5

SBET 6

SBET 7

SBET8

SBET?

SBETIO

SBETI 1

SBET12

SBETI3

SBTEL1

SBTEL1-2

SBTEL1-3

SBTEI1-4

SBMETI

SBMET 2

$A \in E T$

AtTSE

AtTEL 1

AtMFT

HA3a

OSRET 1

OSMETI

OSMET 2

OSRCNA

OSRCN 2

VRN 3

TAMET

HVET1

HVET2

HVMET

HVTEL 1

ZCN 8

ZCNI 2

ZCN1 4

ZCN15

ZCN2

ZCN 4

ZCNIO

ZCN1 1

ZCN 16
I

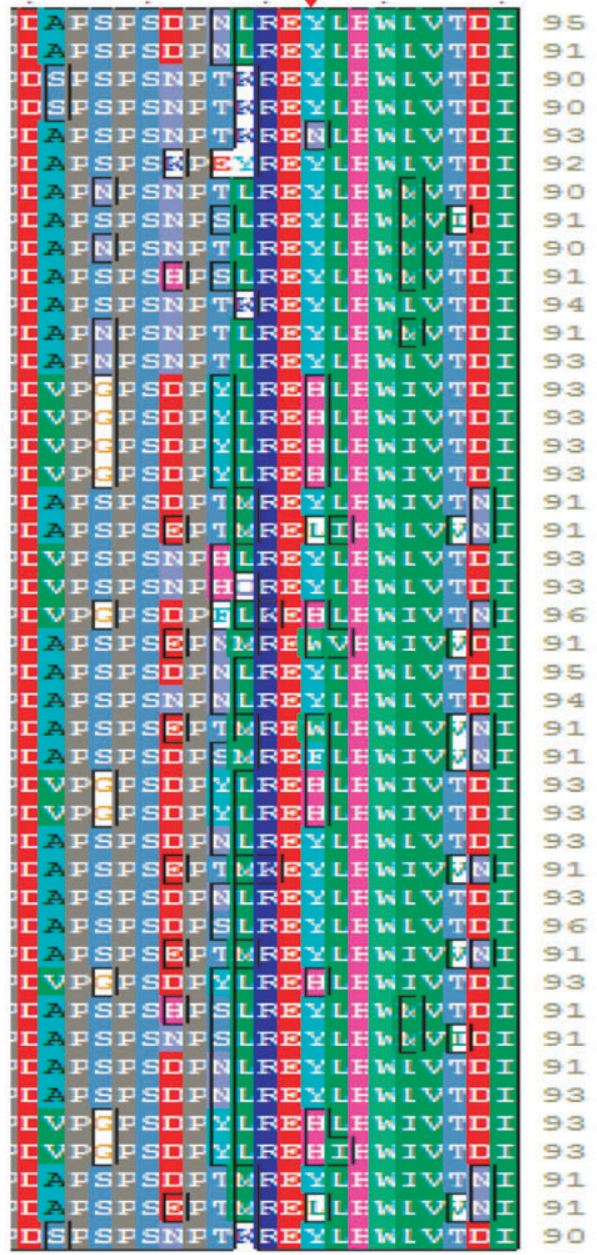

(b)

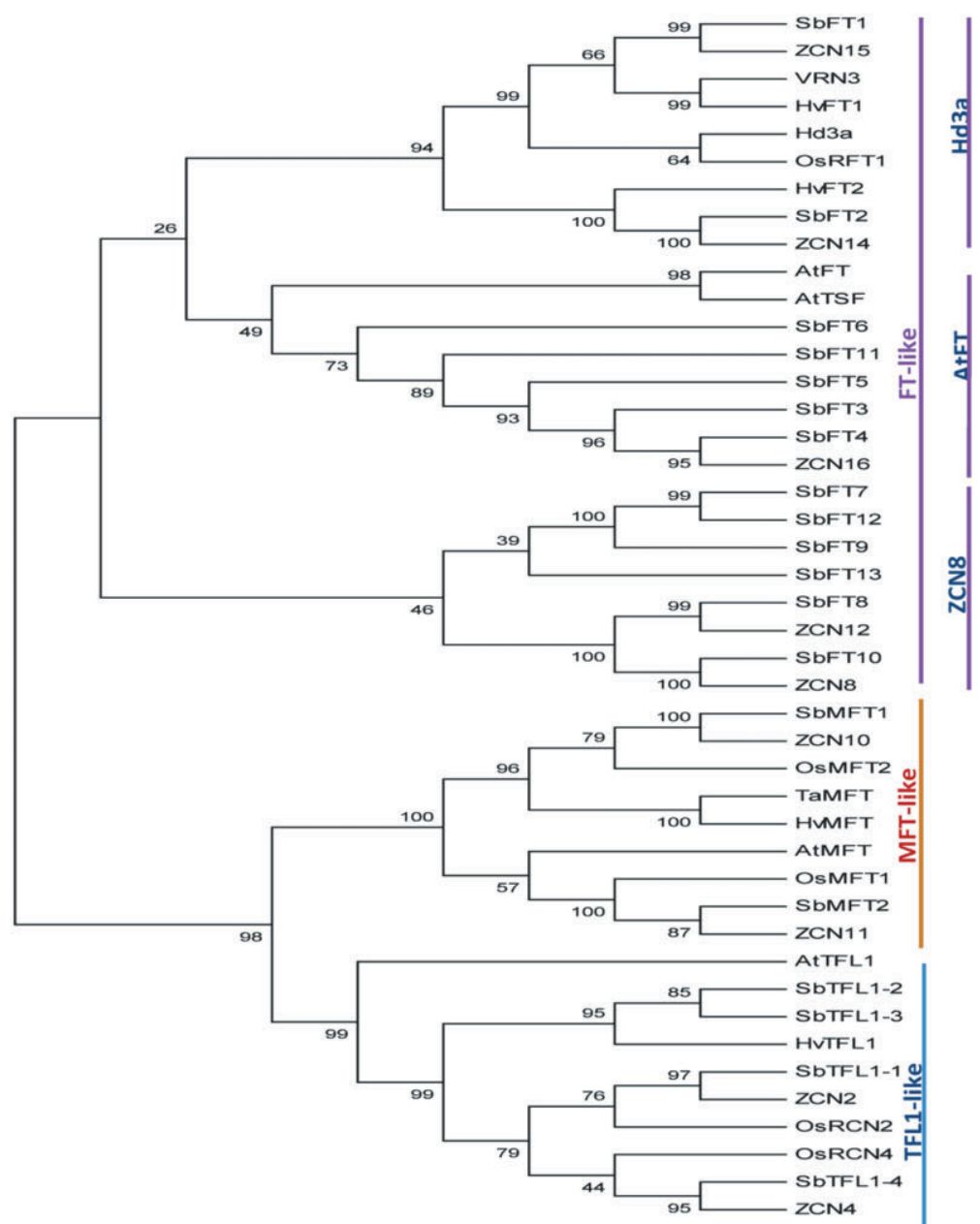

Fig. 1 Amino acid sequence alignment and phylogenetic analysis of 19 sorghum phosphatidylethanolamine binding proteins (PEBPs) and related PEBP proteins. (a) Multiple sequence alignment showing a portion of the PEBP domain where key differences were observed between FT and TFL1-like sequences. The red arrow points to conserved Tyrosine $(Y)$ residue in FT-like or Histidine $(H)$ in TFL1-like sequences. (b) Phylogenetic analysis of $S b F T$, SbTFL1 and SbMFT genes based on the amino acid sequence of the full-length protein. Thirteen sorghum FT-like, four TFL1-like and two MFT-like proteins group into three clades with the corresponding proteins from maize, wheat, barley, rice and Arabidopsis, each node being indicated by solid lines of different color. The FT-like clade is further subdivided into ZCN8, AtFT and Hd3a subclades. Numbers on branches indicate bootstrap values for 1000 replicates.

accumulation of transcripts of SbFT1, SbFT8 and SbFT10 started to increase at $c .4 \mathrm{~h}$ after the light was turned off, peaked within $2 \mathrm{~h}$ and started to decline gradually, reaching basal levels at $c .2 \mathrm{~h}$ after the light was turned on (Fig. $2 \mathrm{~b}, \mathrm{c}$ ). All three genes showed a similar pattern but SbFT1O showed the greatest, while SbFT1 showed the least, induction in the dark. The SbFT1 induction peak was slightly broader, extending more into dawn (Fig. 2b). These results suggest that all the three SbFT genes are regulated with a similar diurnal pattern but with different induction strength.

SbFT1, SbFT8 and SbFT10 are expressed in grain sorghum and early-flowering mutants but not in sweet sorghum and forage sorghum genotypes under LD conditions.

Grain sorghum genotypes Tx430 and BTx623 are photoperiodinsensitive and flower early irrespective of day length, whereas sweet sorghum genotypes Theis and Rio as well as commercial forage sorghum hybrids FS000504 and FS000991 are photoperiodsensitive and flower early under SD conditions but late under LD conditions. We tested the expression patterns of SbFT1, SbFT8 and SbFT1O in these six different genotypes grown under LD conditions to evaluate if sorghum $F T$ genes account for variation in flowering time and photoperiod sensitivity. Fully expanded top leaf samples were collected from each genotype at dawn at a growth stage corresponding to the transition period in grain sorghum. We found that the transcripts of SbFT1, SbFT8 and SbFT10 were highly abundant in grain sorghum genotypes, but consistently very weak or absent in sweet and forage sorghum genotypes (Fig. 3a). On the other hand, expression of a nonflorigen candidate, SbFT9, showed no difference between photoperiod-sensitive and -insensitive genotypes (Fig. 3a).

We further determined the expression patterns of these three SbFTs in the available sorghum classical flowering mutants. 
(a)

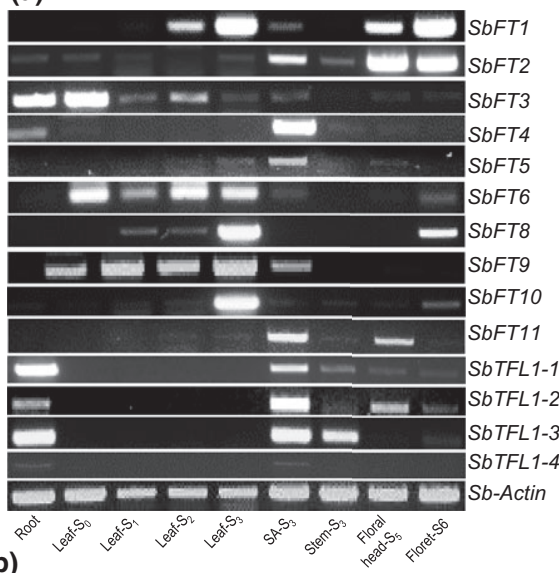

(b)

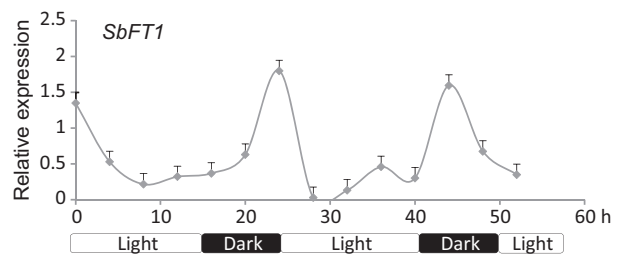

(c)

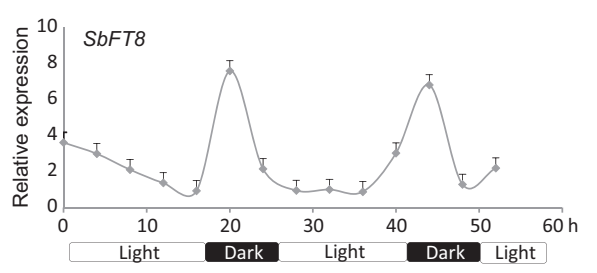

(d)

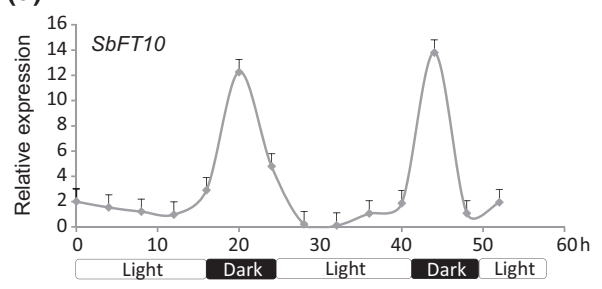

Fig. 2 Spatial and diurnal expression pattern analyses of sorghum PEBP genes. (a) Expression pattern analysis of sorghum SbFT/ $S B T F L 1$-like genes in different tissues of grain sorghum BT×623 at different growth stages analyzed by semi-quantitative reverse transcription polymerase chain reaction (RTPCR). S0-S6 refer to the sorghum developmental stages. SA, shoot apex. (b-d) Diurnal expression pattern of SbFT1 (b), SbFT8 (c) and SbFT10 (d) in fully expanded leaf blades of grain sorghum of BTx623 under long-day (LD) conditions near the floral initiation period. Transcripts were analyzed by real-time quantitative RT-PCR during $52 \mathrm{~h}$ in the $24 \mathrm{~h}$ diurnal cycle relative to the ACTIN control. Error bars, $\pm \mathrm{SE}$. The light periods are shown in white boxes, and the dark periods are shown in black boxes. (a)

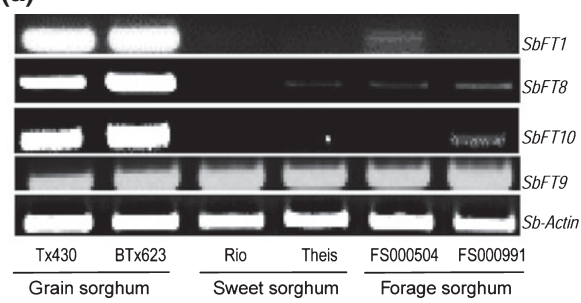

(b)

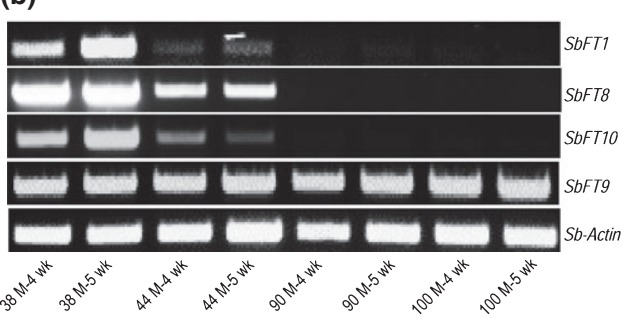

(c)

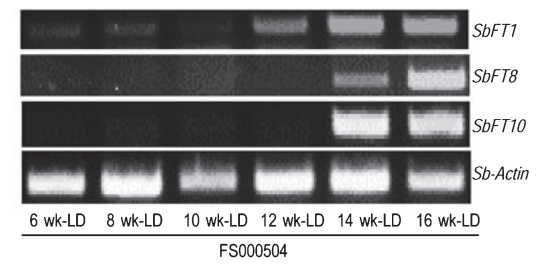

(d)

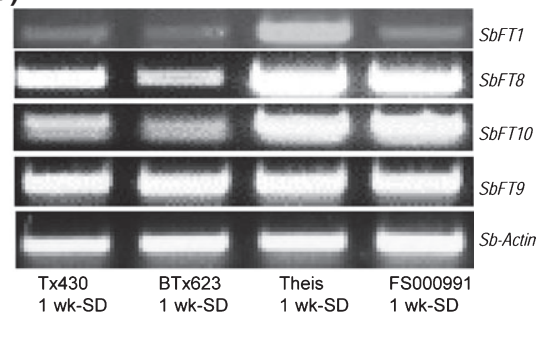

Fig. 3 Expression level of four SbFT-Like genes in leaves of different sorghum genotypes under short-day (SD) and long-day (LD) conditions. (a) Expression levels of SbFT1, SbFT8, SbFT9 and SbFT10 in the leaves of grain, sweet and forage sorghum genotypes 4 wk after germination under LD conditions. (b) Expression levels of SbFT1, SbFT8, SbFT9 and SbFT10 in the leaves of different sorghum natural mutant lines and a parental control at 4 and 5 wk after germination under LD conditions. (c) Expression patterns of SbFT1, SbFT8 and SbFT10 in the leaves of late-flowering forage sorghum (FS000504) at different stages of development under LD conditions.(d) Expression levels of SbFT1, SbFT8, SbFT9 and SbFT10 in the leaves of grain, sweet and forage sorghum at the seedling stage in response to $1 \mathrm{wk}$ SD treatment. Transcript expression levels were determined by semiquantitative RT-PCR using sorghum ACTIN as a loading control.

Sorghum flowering mutants have long been identified by genetic selection based on the presence $(M a)$ or absence $(m a)$ of one or more maturity loci that modify photoperiod sensitivity (Quinby, 1973). The early-flowering mutants of sorghum, 38M ( $\mathrm{mal}$, $\left.\overline{m a 2}, m a 3^{R}\right), 44 \mathrm{M}\left(m a 2, m a 3^{R}\right)$, near control $90 \mathrm{M}(m a 3)$ and the control 100M (Ma1, Ma2, Ma3, Ma4) were grown under LD glasshouse conditions. $m a 3^{R}$ is a strong allele of ma3. Leaf samples were collected from each line at 4 and 5 wk after emergence for transcript analysis. We found that the transcripts of SbFT1, SbFT8 and SbFT1O were highly abundant in the earliest flowering line $38 \mathrm{M}$, followed by $44 \mathrm{M}$, but consistently below detection in $90 \mathrm{M}$ and $100 \mathrm{M}$ at this developmental stage (Fig. 3b). 38M is slightly earlier heading than $44 \mathrm{M}$ and even this difference was reflected by the expression levels of the three SbFT 
genes. By contrast, SbFT9 expression showed no difference in all the tested lines (Fig. 3b). Together these results demonstrate that expression of the three sorghum FT genes, SbFT1, SbFT8 and $S b F T 10$, is additively repressed by maturity loci, suggesting that these SbFT genes are involved in promoting flowering in sorghum and may account for differences in flowering time and photoperiod sensitivity between sorghum genotypes.

\section{Expression of three sorghum $F T$ genes is induced by plant age and SD photoperiod in late-flowering genotypes}

The forage hybrid FS000504 is the latest flowering line we have and takes $22 \mathrm{wk}$ to heading under our LD (16:8 h, light: dark cycle) conditions. We determined the time at which the SbFT genes are expressed in this genotype under LD conditions by collecting leaf samples at dawn with $2 \mathrm{wk}$ intervals. We found that SbFT1 was first detected at $12 \mathrm{wk}$ after emergence and SbFT8 and SbFT1O were also clearly induced by $14 \mathrm{wk}$ (Fig. 3c). As this genotype heads in $22 \mathrm{wk}, 14 \mathrm{wk}$ probably represents the initiation of the floral transition period and suggests that the three sorghum $F T$ genes are induced at the time of floral transition in FS000504, although this occurred $10 \mathrm{wk}$ later than that of grain sorghum.

To determine if SD photoperiod can induce the expression of sorghum $F T$ genes in both photoperiod-insensitive and -sensitive genotypes, we examined the expression patterns of SbFT1, SbFT8 and SbFT10 in grain, sweet and forage sorghum genotypes grown under SD $(8: 16 \mathrm{~h}$, light: dark cycle) conditions. Leaf samples were collected from each genotype at dawn at $1 \mathrm{wk}$ after emergence. Interestingly, the transcripts of SbFT1, SbFT8 and SbFT1O were detected in most genotypes with the highest induction observed in the sweet sorghum Theis (Fig. 3d). Induction of SbFT1 appeared to be the weakest and SbFT8 the strongest in all the genotypes tested, but generally the sweet and forage sorghums appeared to induce all the three FT genes more strongly than the grain sorghums (Fig. 3d), suggesting that SbFT1, SbFT8 and SbFT10 promote flowering in photoperiodsensitive genotypes in response to short days, and SD induction of these genes, especially that of $S b F T 1$, is attenuated in grain sorghum genotypes. Rio and FS000504 require $3 \mathrm{wk}$ to induce at least SbFT8 and SbFT10 in response to SDs (Fig. S2), suggesting a minimum SD saturation requirement for $S b F T$ gene induction depending on genotype.

We next asked whether the SD treatment can be remembered and the $1 \mathrm{wk}$ high induction of $F T$ genes in Theis is sufficient for floral promotion after transferring to LDs. To address this, we grew Theis under SD conditions for one to several weeks and at the end of each treatment, plants were transferred to LD conditions. Leaf samples were collected at the end of each treatment while plants were still on SDs and after transfer to LDs at the specified period, and $F T$ transcript abundances were compared with controls grown continuously under LD conditions. Expression of SbFT1, SbFT8 and SbFT1O genes was highly induced in Theis within 1 wk of SD conditions as described earlier and remained high at least in the second week of SDs (Fig. 4a). However, when SD-treated plants were transferred to LD conditions for $1 \mathrm{wk}$, the expression level of all three genes reduced dramatically to undetectable levels (Fig. 4a), indicating that 1 wk growth under LD conditions was sufficient to completely reverse induction even after 6 wk of SD photoperiods. This suggests that there is no long-term memory for SbFT induction by SDs and the three $S b F T$ transcripts were probably quickly destabilized by LD photoperiods in Theis.

However, the growth response appeared to be more complex. Theis grown constantly under $\mathrm{LD}$ conditions took $c$. $140 \mathrm{~d}$ to heading, while this was achieved in c. $70 \mathrm{~d}$ when grown constantly under SD conditions (Fig. 4d). When plants were transferred from 1 to 4 wk growth under SDs to LDs, vegetative growth continued with the same shoot (Fig. 4c), but when plants were transferred at the fifth week and after, growth of the original shoot was arrested and new shoot growth was initiated from a lower node (Fig. $4 \mathrm{~d}-\mathrm{h}$ ). This happened even when plants were transferred after heading (Fig. 4h). Interestingly, plants transferred after 7 wk under SD conditions started heading at the ninth week under LD conditions (Fig. 4f) while the control was still vegetative (Fig. 4b). These results suggest that the LD photoperiod is dominant in reversing SbFT induction and growth stages established under SDs, but some aspects of the floral transition may still be activated by the SD treatment provided that the SD treatment lasts $7 \mathrm{wk}$ or more in the case of Theis.

\section{Functional analyses of sorghum FT genes in transgenic Ara- bidopsis}

To confirm that the biological function of SbFT1, SbFT8 and SbFT1O is indeed activation of flowering, we transformed each of these genes into Ler driven by the $2 \times 35$ S promoter. Under LD conditions, all SbFT1 transgenic lines had at most two rosette leaves $(1.1 \pm 0.9)$ at flowering compared with eight to nine $(8.4 \pm 1.0)$ in Ler (Fig. 5a-c,i), where 36\% flowered without forming any rosette leaves, indicating strong activation of flowering. In addition, 10 of these transgenic lines were evaluated in the T2 generation for early flowering under SD conditions. All of the 10 T2 lines flowered with two to three rosette leaves compared with 10-12 in Ler (Fig. 5d), indicating activation of flowering in transgenic Arabidopsis both under LD and SD conditions. We further tested the ability of 35S:SbFT1 to complement the late-flowering Arabidopsis $f t-1$ mutant. Complemented transgenic plants flowered early with zero to two rosette leaves at bolting under LD conditions compared with the $f t-1$ mutant, which produced $12-15$ rosette leaves at bolting (Figs $5 \mathrm{i}$, S3a,c). This indicates that SbFT1 ectopic expression not only complements the $f t-1$ late-flowering phenotype but also induces early flowering in the mutant background.

On the other hand, all 35S::SbFT8 transgenic lines in Ler flowered before bolting with two tiny up-curled cauline leaves (Fig. 5e,i) and died without setting seeds, suggesting that SbFT8 is probably more active and its high expression is lethal for the plants. Alternatively, SbFT8 may regulate vegetative growth and plant architecture in addition to activation of flowering in sorghum. Furthermore, 35S::SbFT8 expression in the $f t-1$ mutant 
(a)



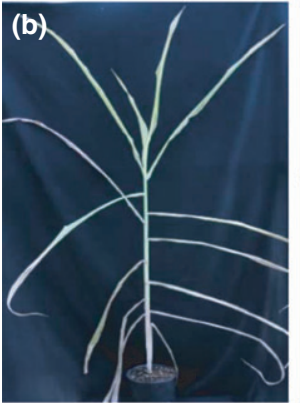

16 wk LD

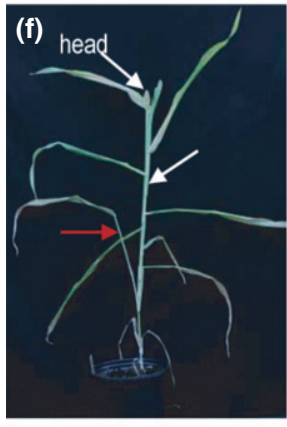

$7 w k$ SD $+9 w k$ LD

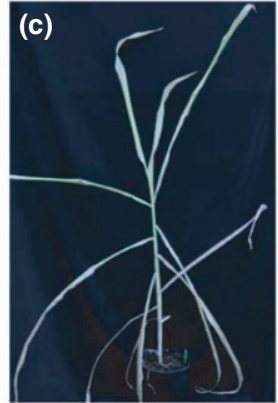

1 wk SD + 15 wk LD

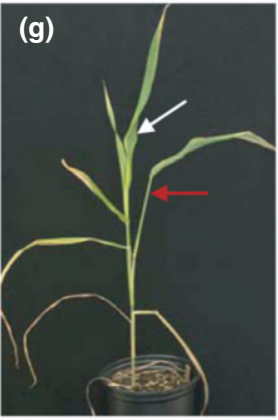

$8 w k S D+4 w k$ LD

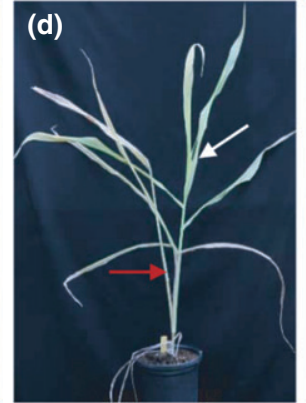

5 wk SD + 11 wk LD

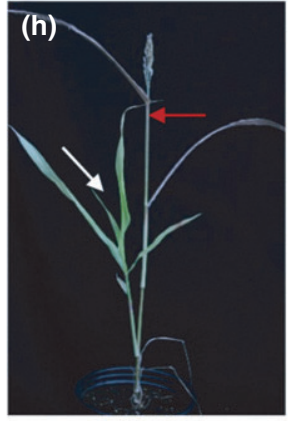

$11 w k$ SD + 5 wk LD



6 wk SD + $10 w k$ LD

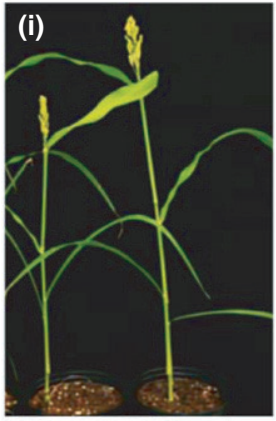

10 wk SD
Fig. 4 SbFT gene expression and growth response of Theis to short-day (SD) and long-day (LD) treatments. (a) Transcript accumulation of SbFT1, SbFT8, SbFT9 and SbFT10 in the leaves of Theis after exposure to SD, LD or SD + LD conditions for specified periods. For SD + LD treatment, plants were grown under SD conditions for 1-6 wk and transferred to LD conditions for 6-1 wk before sampling. $(b, i)$ Phenotype of Theis plants grown continuously under LD and SD conditions for 16 and $10 \mathrm{wk}$, respectively. (c-h) Phenotype of Theis plants first grown under SD conditions for the specified 1-11 wk and shifted to LD conditions for the specified 4-15 wk. Note that in (d-h), the first shoot grown under SD conditions is arrested (red arrow) and a new shoot then developed from the lower node (white arrow) after transfer to the LD conditions. resulted in very early flowering with zero to two rosette leaves at bolting under LD conditions (Figs 5f,i, S3d,e), suggesting that SbFT8 is, indeed, a strong activator of flowering. The fact that SbFT8-expressing $f t-1$ mutant plants survived better than SbFT8expressing Ler plants suggests that the very high expression of SbFT8 is most probably the cause for the observed defects.

As we used a vector (pMDC32) that drives very high expression with $2 \times 35 \mathrm{~S}$ promoter in all our transformations, high expression of SbFT10 led to an even worse phenotype and resulted in lethality, and therefore we were unable to obtain enough SbFT10 transgenic lines for further analysis. Consequently, we resorted to a weaker promoter, STENOFOLIA (STF) from Medicago truncatula, to obtain transgenic lines for SbFT10. The STF promoter drives expression in the leaf margin and middle mesophyll at the adaxial-abaxial junction including the vascular region but not in the shoot apical meristem (Tadege etal., 2011). STF: SbFT10 expression resulted in early flowering with four phenotypic classes: flowering without bolting with two upcurled leaves (17\%) which died without setting seeds (Fig. 5g); bolting with two to three up-curled leaves and terminal flower (50\%) (Fig. S3f); bolting with four rosette leaves (23.5\%) (Fig. S3g); and later-flowering, bushy plants bolting with nine or more rosette leaves (9.5\%). The STF::SbFT10 construct also complemented the $f t-1$ mutant in LD conditions with an average of 1.8 rosette leaves at bolting (Fig. 5h,i). These results suggest that SbFT10 activates flowering in Arabidopsis perhaps more strongly than SbFT8 because a weaker promoter (STF) was required to obtain $S b F T 10$-expressing transgenic Arabidopsis plants. Alternatively, SbFT10 may have other functions in addition to activation of flowering which became detrimental in Arabidopsis with a very strong constitutive promoter. These transgenic analyses are consistent with the spatial, temporal and diurnal expression patterns, as well as the day length response and genotype-dependent expression of SbFT genes, and together 



Fig. 5 Phenotype of transgenic Arabidopsis plants transformed with sorghum FT genes. (a, b) Untransformed Landsberg erecta (Ler) control. (c) Phenotype of 35S::SbFT1 transgenic plants under long-day (LD) conditions. (d) Phenotype of 35S::SbFT1 transgenic plants (upper panel) vs Ler (lower panel) under short-day (SD) conditions. (e) Phenotype of 35S::SbFT8 transgenic plant flowering at the cotyledon stage without bolting under LD conditions. (f) Phenotype of $\mathrm{ft}-1$ mutant transformed with $35 \mathrm{~S}::$ SbFT8 showing early flowering with a terminal flower phenotype under LD conditions. (g) Strong earlyflowering phenotype of transgenic Ler plant transformed with STF::SbFT10 under LD conditions. (h) Phenotype of ft-1 mutant transformed with STF:: SbFT10 showing early flowering under LD conditions. (i) Flowering time of SbFT1, SbFT8 and SbFT10 transgenic Arabidopsis plants compared with Ler and $\mathrm{ft}-1$ mutant under LD conditions measured by rosette leaf number at bolting. Error bars, $\pm \mathrm{SE}$.

suggest that sorghum has at least three functional $F T$ genes that can promote floral activation.

\section{SbFT2, SbFT6 and SbFT9 genes do not induce flowering in transgenic Arabidopsis}

As SbFT2 is expressed in the shoot apex at the floral transition stage and SbFT6 and SbFT9 are expressed in leaves at all stages of development (Fig. 2a), these three genes were further tested for their potential candidacy. The three genes were introduced into Ler and the $f t-1$ mutant individually driven by the $35 \mathrm{~S}$ promoter. Our results revealed that none of these genes activated flowering in Ler or rescued the late-flowering $\mathrm{ft}-1$ mutant (Fig. S4), suggesting that SbFT2, SbFT6 and SbFT9 are probably not involved in the activation of flowering in sorghum.

\section{SbFT1, SbFT8 and SbFT10 proteins may interact with SbFD1 and/or Sb14-3-3}

We performed $\mathrm{Y} 2 \mathrm{H}$ and $\mathrm{BiFC}$ assays to determine whether the SbFT encoded proteins are capable of interacting with AtFD, SbFD1 and Sb14-3-3. Our results showed that SbFT1 but not SbFT8 and SbFT10 proteins interact with AtFD and SbFD1 in the $\mathrm{Y} 2 \mathrm{H}$ assay under stringent conditions (Fig. S5a). We also tested whether SbFT1, SbFT8 and SbFT10 interact with each other. SbFT1 interacted with both SbFT8 and SbFT10 and also showed self-interaction, while SbFT8 and SbFT10 neither interacted with each other nor showed self-interaction in the $\mathrm{Y} 2 \mathrm{H}$ assay (Fig. S5b). However, the BiFC assay using split YFP complementation in $N$. benthamiana leaf cells identified that the three sorghum FTs can interact with AtFD and SbFT1 interacted with 
(a)
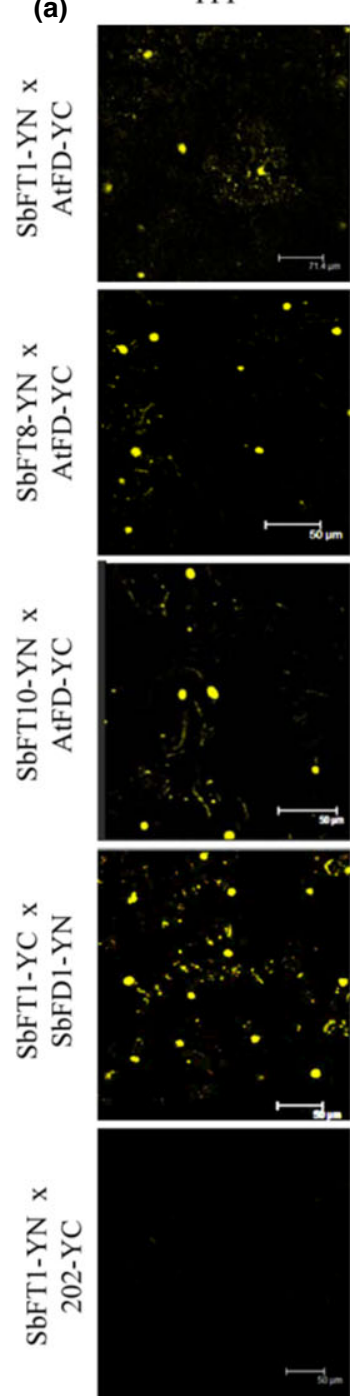

Merge
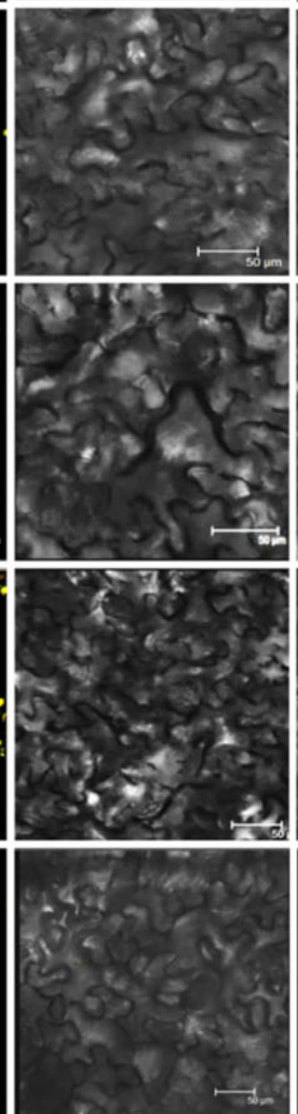
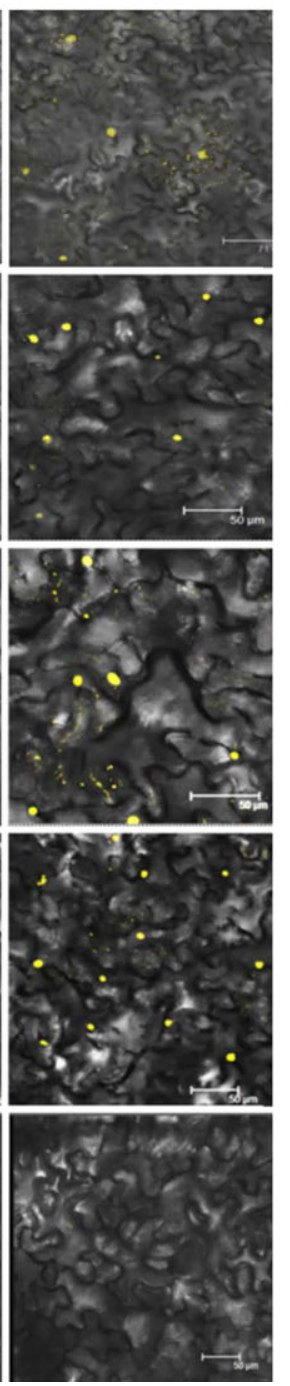

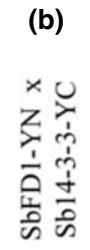

YFP
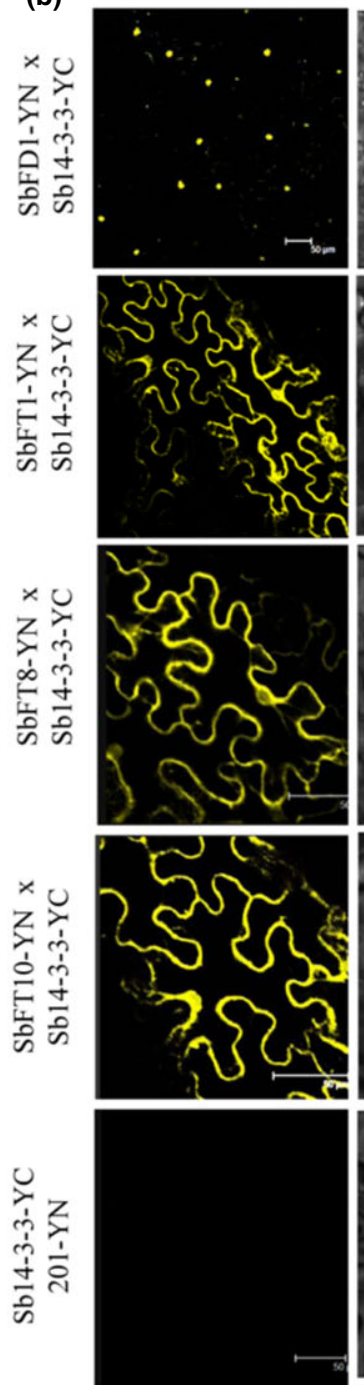

Bright field
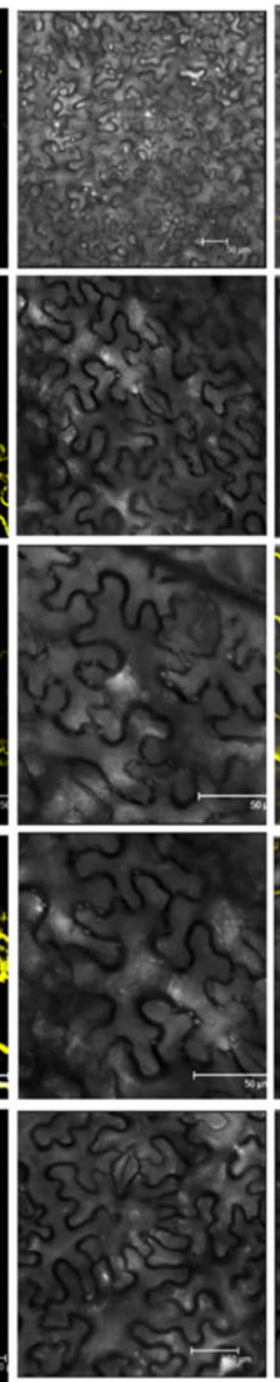

Merge
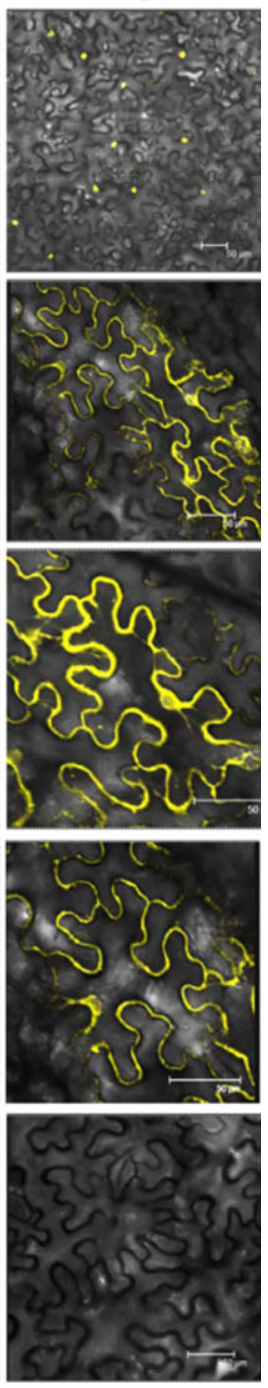

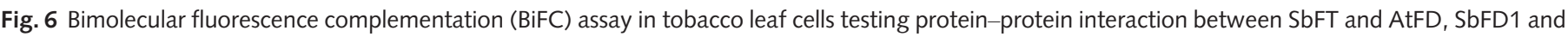

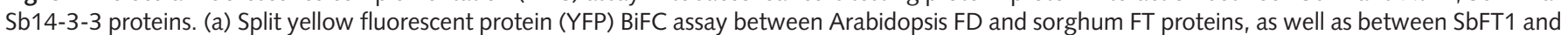

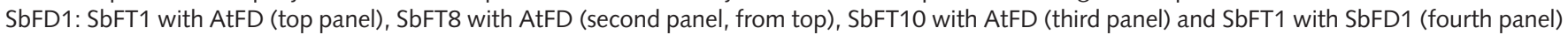
where the FTs were fused to the $\mathrm{N}$-terminal half while FD was fused to the C-terminal half of YFP. Reconstitution of yellow fluorescence shows positive

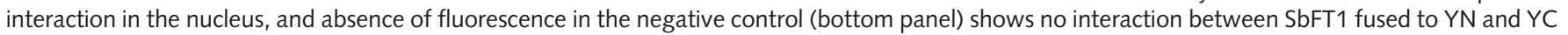

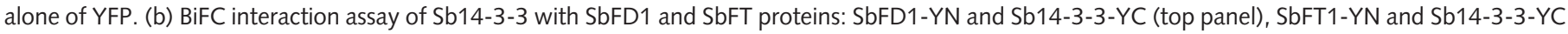

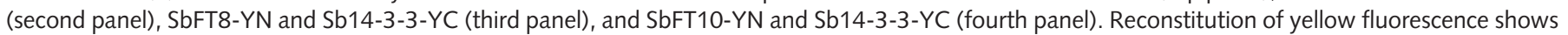
positive signal in the nucleus for the interaction of SbFD1 with Sb14-3-3 and in the cytoplasm for the interaction of Sb14-3-3 with SbFTs. The control (bottom panel) shows an absence of interaction between Sb14-3-3-YC and YN alone.

SbFD1 (Fig. 6a). However, SbFT8 and SbFT10 did not show interaction with SbFD1 in the BiFC assay (Fig. S6a). We also cloned the sorghum homolog of rice GF14C, Sb14-3-3, and tested interactions with SbFTs in the $\mathrm{Y} 2 \mathrm{H}$ and $\mathrm{BiFC}$ assays. In the $\mathrm{Y} 2 \mathrm{H}$ assay, only SbFT1 but not SbFT8 and SbFT10 interacted with Sb14-3-3 (Fig. S5a), but in the BiFC assay SbFT1, SbFT8 and SbFT10 all interacted with Sb14-3-3 in the cytoplasm, and SbFD1 interacted with Sb14-3-3 in the nucleus (Fig. 6b). SbFT1, SbFT8 and SbFT10 were localized in both the nucleus and the cytoplasm, while Sb14-3-3 was exclusively localized in the cytoplasm (Fig. S6b), but interaction of Sb14-3-3 with SbFD1 occurred in the nucleus, suggesting that all three
SbFT proteins are potentially capable of forming a floral activation complex with Sb14-3-3 and SbFD1 in the nucleus of living plant cells. Consistent with this, ectopic expression of SbFT1, SbFT8 and SbFT10 but not SbFT9 induced expression of floral meristem identity genes $A P 1$ and $L F Y$ in transgenic Arabidopsis (Fig. S7).

\section{Discussion}

Control of flowering time is a major agronomic trait in sorghum that dictates its usage in grain or biomass production in temperate regions. Owing to its original domestication in tropical East 
Africa, sorghum exhibits strong photoperiod response. However, sorghum has been introduced into temperate agriculture where photoperiod-insensitive varieties have been developed for optimum seed production in the warm summer months. We examined 19 PEBP sequences from the sorghum genome (version 2.1) and identified 13 FT-like genes, SbFT1-SbFT13, in an effort to understand the mechanistic control of flowering time in sorghum. Of the 13 FT-like genes, SbFT1, SbFT8 and SbFT10 were identified as potential candidates for encoding florigens that activate floral transition and mediate photoperiodic responses. SbFT1 is most closely related and syntenic to rice $H d 3 a$, and was previously reported as sorghum FT (Murphy etal., 2011), whereas SbFT8 and SbFT10 were reported as SbCN12 and $S b C N 8$, respectively, analogous to the maize $Z C N 12$ and $Z C N 8$ genes (Yang et al., 2014a,b). As ZCN8 appeared to be the only florigen candidate in maize (Lazakis etal., 2011; Meng et al., 2011) but there are three candidates in sorghum, we retained the original naming ' $F T$ ' to avoid confusion. Our results indicated that although $S b F T 1$ exhibits the lowest transcript accumulation under SD conditions, all three genes, SbFT1, SbFT8 and SbFT10, are induced by SDs especially in photoperiod-sensitive genotypes, expressed in leaves at the time of floral transition irrespective of genotype and day length, expressed early in earlyflowering lines and late in late-flowering lines under LD conditions, interact with sorghum 14-3-3 in BiFC assays, and strongly activate flowering in transgenic Arabidopsis. These observations are consistent with all three genes being floral transition activators, and may function redundantly to control flowering in sorghum.

Having two florigens is not uncommon, as exemplified by $F T$ and TSF in Arabidopsis (Yamaguchi et al., 2005) and Hd3a and RFT1 in rice (Komiya et al., 2008). However, it is intriguing that sorghum may have at least three functional $F T s$, while maize, with a much larger genome, appears to have one functional $F T$, ZCN8 (Lazakis et al., 2011; Meng et al., 2011). Sorghum is a close relative of maize and the two are assumed to have shared a common ancestor as recently as 24 million yr ago (Thomasson et al., 1986); therefore a one-to-one correspondence of sorghum to maize genes might be expected. Indeed, all of the sorghum PEBP genes, except SbFT13, have close homologs in maize (Table S2) (Danilevskaya et al., 2008b). But, despite the existence of the SbFT1 homolog with $97 \%$ amino acid identity, ZCN15, at the syntenic region on chromosome 6 of maize, this gene appears not to be involved in maize flowering (Meng etal., 2011). However, SbFT8 and SbFT10 are more closely related to the maize $Z C N 8$ than to rice $H d 3 a$ or RFT1 (Fig. 1b; Table 1), and are syntenic to $Z C N 12$ and $Z C N 8$, respectively. It appears that sorghum has retained floral activation function for three genes, SbFT1, SbFT8 and SbFT10, equivalent to maize ZCN15, $Z C N 12$ and $Z C N 8$ in which SbFT1 is also collinear to rice $H d 3 a$ and maize ZCN15 (Danilevskaya et al., 2008a), although ZCN15 appears not to play a role in floral activation in maize. However, not all $Z C N$ genes are completely excluded from potential candidacy for florigen. For example, ZCN12 is expressed in leaf and induced by SD treatment (Danilevskaya et al., 2008a; Meng et al., 2011), suggesting a potential for floral activation in maize.
Thus, with the possibility of additional functional $Z C N$ genes in maize, the regulation of floral transition in maize and sorghum may not be that different after all. Further experiments with mutants or reduced expression lines will be required to quantitatively determine the contribution of each of the three SbFT genes to sorghum flowering and photoperiod response.

\section{Sorghum FT genes are additively repressed by maturity loci in LDs but repression is overcome by SD treatment}

In the photoperiod-insensitive grain sorghum genotype, BTx623, the expression of SbFT1, SbFT8 and SbFT10 under LD conditions is regulated by plant age in which expression of all three genes is barely detectable at the seedling stage but sharply increases near the floral transition period (Fig. 2a), suggesting that endogenous factors regulate $F T$ expression and flowering in this genotype. SbFT1, 8 and 10 are also highly expressed in leaves at the S3 stage in other early-flowering genotypes, such as $38 \mathrm{M}$ and Tx430, but not in $100 \mathrm{M}$, forage and sweet sorghums (Fig. 3), suggesting repression by maturity loci. This repression appeared to be additive. In $38 \mathrm{M}\left(\mathrm{ma} 1, \mathrm{ma} 2, \mathrm{ma} 3^{R}\right)$, all three $S b F T$ genes are highly expressed $5 \mathrm{wk}$ after germination, but in $44 \mathrm{M}\left(\mathrm{ma} 2, \mathrm{ma}^{R}\right)$ expression of SbFT1 and SbFT10, in particular, is highly reduced, and in $90 \mathrm{M}(\mathrm{ma} 2)$ or $100 \mathrm{M}$ ( Ma1, Ma2, Ma3, Ma4), expression of the three genes is not detectable (Fig. 3b). This shows that the maturity loci, at least $\mathrm{Ma1}, \mathrm{Ma} 2$ and Ma3, may cooperatively repress the expression of SbFT1, 8, 10 genes under LD conditions, consistent with the genetic data showing that maturity loci together have the strongest effect on flowering (Quinby \& Karper, 1945; Quinby, 1966, 1973; Rooney \& Aydin, 1999; Morgan \& Finlayson, 2000). The two loci that have major effects on flowering, Mal and Ma3, encode PRR37 and PHYB proteins, respectively (Foster et al., 1994; Childs et al., 1997; Murphy et al., 2011). PHYB is an upstream activator of $P R R 37$ and represses $S b F T$ expression by repressing the SbFT activator SbEHD1 through PRR37 (Murphy etal., 2011; Yang et al., 2014a,b). But there is a significant difference in $S b F T$ expression between $38 \mathrm{M}$ and $44 \mathrm{M}$ (Fig. 3b), which suggests that $P H Y B$ affects $S b F T$ expression in addition to its effect through PRR37 accounting for cooperative repression. This may be through activating other repressors such as SbGHD7 (Yang et al., 2014a), other phytochromes, the circadian clock, or directly repressing SbEHD1 or SbFTs. Further experiments will establish whether two or more of these possibilities are correct and whether the three SbFTs are differentially regulated by these upstream repressors.

Nevertheless, repression is fully overcome by growth under SD conditions. Our results with the SD to LD shift experiments suggest that there may not be intact long-term memory for SD treatment, as SbFT expression under SD conditions was completely repressed by just 1 wk at LD photoperiods (Fig. 4a). However, the SD memory is not all lost, as it makes some contribution to the early flowering of plants shifted to LDs (Fig. 4f) depending on the length of the SD treatment before shifting. A phenomenon related to this, called night break, is known in rice and other species, where a short light break during the long night 
interrupts the SD response in a dosage-dependent manner (Ishikawa et al., 2004, 2005, 2009; Higuchi et al., 2012). This situation in rice favors the possibility of the presence of a separate maintenance factor of $\mathrm{Hd} 3 \mathrm{a}$ induction by SDs, which would be sensitive to dosage-dependent exposure to light. On the other hand, the strict day length control in rice mediated by repressor GHD7 and activator EHD1 functions on $\mathrm{Hd} 3 \mathrm{a}$ expression (Itoh et al., 2010) could tip the balance to the GHD7 side with additional light exposure without necessarily having a separate factor for maintenance of $H d 3 a$ induction. GHD7 and EHD1 orthologs have been reported in sorghum (Murphy et al., 2011; Yang et al., $2014 \mathrm{a}, \mathrm{b})$ and, in fact, SbGHD7 is encoded by MaG, one of the maturity loci that modifies the photoperiod response (Murphy et al., 2014). Further molecular analyses are needed to understand the mechanism with which reversion of $F T$ induction by LDs, memory of exposure to SDs, as well as de-repression of the axillary meristem during photoperiod switching are achieved in sorghum, which will provide novel mechanistic insights into the response of sorghum developmental programs to environmental signals.

\section{All three SbFT proteins physically interact with Sb14-3-3 but not necessarily with SbFD1}

In Arabidopsis, rice and maize, the FT-FD protein interaction in the shoot apical meristem is required to directly activate transcription of floral meristem identity target genes. In rice, $\mathrm{Hd} 3 \mathrm{a}$ interacts with OsFD1 via a 14-3-3 protein (Taoka et al., 2011; Hiroyuki et al., 2013), which appears to be a cytoplasmic receptor for Hd3a (Taoka et al., 2011, 2013). The 14-3-3-Hd3a complex translocates to the nucleus to bind with OsFD1 and thereby activate OsMADS15 transcription (Taoka et al., 2011, 2013; Hiroyuki et al., 2013). Our analysis suggests that this type of interaction may also be conserved in sorghum. SbFT1 but not SbFT8 and SbFT10 interact with SbFD1 in Y2H and BiFC assays (Figs 6, S5, S6). However, SbFT1 interacts with SbFT8 and SbFT10 in the Y2H assay, and all three SbFTs interact with Sb14-3-3 in the BiFC assays in the cytoplasm while SbFD1 interacts with Sb14-3-3 in the nucleus (Fig. 6b). It is thus likely that SbFT8 and 10 interact with SbFD1 in the nucleus through Sb14-3-3, analogous to the situation in rice. The significance of SbFT1 interaction with SbFT8 and 10 is unclear at this point, but it is possible that SbFT1 facilitates or stabilizes the SbFT8 and 10 interaction with SbFD1 in the nucleus. These observations together suggest that SbFT8 and SbFT10 may interact with SbFD1 through Sb14-3-3 and it is likely that a SbFT-Sb14-3-3SbFD1 floral activation complex could form in the nucleus, although this remains to be demonstrated. Consistent with these, all three SbFTs induced expression of AtLFY and AtAP1, and activated early flowering in transgenic Arabidopsis.

Our results together demonstrate that sorghum has at least three $F T$ genes that could potentially form an FAC and mediate genotype-dependent photoperiod response and flowering time variation in sorghum. As flowering is a key agronomic trait in sorghum, the three SbFT genes identified here can be used as valuable molecular markers in sorghum breeding programs.

\section{Acknowledgements}

We thank Drs Bill Rooney and Peggy Lemaux for kindly providing BTx623 and Tx430 seeds, and Ismail Dweikat for kindly providing Theis and Rio seeds. We are grateful to USDA-ARS, GRIN for supplying $38 \mathrm{M}, 44 \mathrm{M}, 90 \mathrm{M}$ and $100 \mathrm{M}$ seeds. This material is based upon work that is supported by the National Institute of Food and Agriculture, US Department of Agriculture, under award numbers 2013-69005-21284 and 201567014-22888.

\section{Author contributions}

T.W.W., F.Z. and M.T. planned and designed the research. T.W.W., F.Z., L.N. and S.K. performed experiments. T.W.W., F.Z., P.B-M., M.G.M. and M.T. analyzed the data. T.W.W. and M.T. wrote the manuscript.

\section{References}

Abe M, Kobayashi Y, Yamamoto S, Daimon Y, Yamaguchi A, Ikeda Y, Ichinoki H, Notaguchi M, Goto K, Araki T. 2005. FD, a bZIP protein mediating signals from the floral pathway integrator FT at the shoot apex. Science 309: 1052-1056.

Chailakhyan MK. 1936. New facts in support of the hormonal theory of plant development. Comptes Rendus Academic Science URSS 1936 13: 79-83.

Chailakhyan MK. 1937. Concerning the hormonal nature of plant development processes. Doklady Akademii Nauk 16: 227-230.

Childs K, Miller F, Cordonnier-Pratt M, Pratt L, Morgan PW, Mullet JE. 1997. The sorghum photoperiod sensitivity gene, Ma3, encodes a phytochrome B. Plant Physiology 113: 611-619.

Clough SJ, Bent AF. 1998. Floral dip: a simplified method for Agrobacteriummediated transformation of Arabidopsis thaliana. Plant Journal 16: 735-743.

Colasanti J, Yuan Z, Sundaresan V. 1998. The indeterminate gene encodes a zinc finger protein and regulates a leaf-generated signal required for the transition to flowering in maize. Cell 93: 593-603.

Corbesier L, Vincent C, Jang S, Fornara F, Fan Q, Searle I, Giakountis A, Farrona S, Gissot L, Turnbull C et al. 2007. FT protein movement contributes to long-distance signaling in floral induction of Arabidopsis. Science 316: $1030-1033$.

Danilevskaya ON, Meng X, Hou Z, Ananiev EV, Simmons CR. 2008a. A genomic and expression compendium of the expanded PEBP gene family from maize. Plant Physiology 146: 250-264.

Danilevskaya ON, Meng X, McGonigle B, Muszyski MG. 2011. Beyond floweringtime. Plant Signaling \& Behaviour 6: 1267-1270.

Danilevskaya ON, Meng X, Selinger DA, Deschamps S, Hermon P, Vansant G, Gupta R, Ananiev EV, Muszynski MG. 2008b. Involvement of the MADSbox gene ZMM4 in floral induction and inflorescence development in maize. Plant Physiology 147: 2054-2069.

Doi K, Izawa T, Fuse T, Yamanouchi U, Kubo T. 2004. Ehd1, a B-type response regulator in rice, confers short-day promotion of flowering and controls FT-like gene expression independently of Hd1. Genes \& Development 18: 926-936.

Foster KR, Miller FR, Childs KL, Morgan PW. 1994. Genetic-regulation of development in Sorghum bicolor shoot growth, tillering, flowering, gibberellin biosynthesis, and phytochrome levels are differentially affected by dosage of the ma ${ }_{3}$ R allele. Plant Physiology 105: 941-948.

Giakountis A, Coupland G. 2008. Phloem transport of flowering signals. Current Opinion in Plant Biology 11: 687-694.

Hanzawa Y, Money T, Bradley D. 2005. A single amino acid converts a repressor to an activator of flowering. Proceedings of the National Academy of Sciences, USA 102: 7748-7753.

Higuchi Y, Sumitomo K, Oda A, Shimizu H, Hisamatsu T. 2012. Day light quality affects the night-break response in the short-day plant chrysanthemum, 
suggesting differential phytochrome-mediated regulation of flowering. Plant Physiology 169: 1789-1796.

Hiroyuki T, Ken-ichiro T, Ko S. 2013. Florigen in rice: complex gene network for florigen transcription, florigen activation complex, and multiple functions. Current Opinion in Plant Biology 16: 228-235.

Ishikawa R, Shinomura T, Takano M, Shimamoto K. 2009. Phytochrome dependent quantitative control of Hd3a transcription is the basis of the night break effect in rice flowering. Genes \& Genetic Systems 84: 179-184.

Ishikawa R, Tamaki S, Yokoi S, Inagaki N, Shinomura T, Takano M, Shimamoto K. 2005. Suppression of the floral activator Hd3a is the principal cause of the night break effect in rice. Plant Cell 17: 3326-3336.

Ishikawa R, Yokoi S, Shimamoto K. 2004. Molecular effects of night break in the photoperiodic control of flowering in rice. Plant and Cell Physiology 45: S66.

Itoh H, Nonoue Y, Yano M, Izawa T. 2010. A pair of floral regulators sets critical day length for Hd3a florigen expression in rice. Nature Genetics 42 : 635-638.

Jaeger KE, Wigge PA. 2007. FT protein acts as a long-range signal in Arabidopsis. Current Biology 17: 1050-1054.

Kardailsky I, Shukla VK, Ahn JH, Dagenais N, Christensen SK, Nguyen JT. 1999. Activation tagging of the floral inducer FT. Science 286: 1962-1965.

Kobayashi Y, Kaya H, Goto K, Iwabuchi M, Araki T. 1999. A pair of related genes with antagonistic roles in mediating flowering signals. Science 286: 19601962.

Kojima S, Takahashi Y, Kobayashi Y, Monna L, Sasaki T, Araki T, Yano M. 2002. Hd3a, a rice ortholog of the Arabidopsis FT gene, promotes transition to flowering downstream of $\mathrm{Hd} 1 \mathrm{under}$ short-day conditions. Plant Cell Physiology 43: 1096-1105.

Komiya R, Ikegami A, Tamaki S, Yokoi S, Shimamoto K. 2008. Hd3a and RFT1 are essential for flowering in rice. Development 135: 767-774.

Komiya R, Yokoi S, Shimamoto K. 2009. A gene network for long-day flowering activates RFT1 encoding a mobile flowering signal in rice. Development 136: 3443-3450.

Koo B, Yoo S, Park J, Kwon C, Lee B, An G, Zhang Z, Li J, Li Z, Paek N. 2013. Natural variation in OsPRR37 regulates heading date and contributes to rice cultivation at a wide range of latitudes. Molecular Plant 6: 1877-1888.

Lazakis C, Coneva V, Colasanti J. 2011. ZCN8 encodes a potential orthologue of Arabidopsis FT florigen that integrates both endogenous and photoperiod flowering signals in maize. Journal of Experimental Botany 62: 4833-4842.

Lifschitz E, Eviatar T, Rozman A, Shalit A, Goldshmidt A, Amsellem Z, Alvarez JP, Eshed Y. 2006. The tomato FT ortholog triggers systemic signals that regulate growth and flowering and substitute for diverse environmental stimuli. Proceedings of the National Academy of Sciences, USA 103: 6398-6403.

Lin M, Belanger H, Lee Y, Varkonyi-Gasic E, Taoka K, Miura E, XoconostleCázares BGK, Jorgensen RA, Phinney B, Lough TJ et al. 2007. FLOWERING LOCUS T protein may act as the long-distance florigenic signal in the cucurbits. Plant Cell 19: 1488-1506.

Lu Q, Tang X, Tian G, Wang F, Liu K, Nguyen V, Kohalmi SE, Keller WA, Tsang EW, Harada JJ et al. 2010. Arabidopsis homologue of the yeast TREX2 mRNA export complex: components and anchoring nucleoporin. Plant Journal 61: 259-270.

Mace E, Tai S, Gilding E, Li Y, Prentis P, Bian L, Campbell B, Hu W, Innes DJHan $\mathrm{X}$ et al. 2013. Whole-genome sequencing reveals untapped genetic potential in Africa's indigenous cereal crop sorghum. Nature Communications 4: 2320.

Mathieu J, Warthmann N, Kt F, Schmid M. 2007. Export of FT protein from phloem companion cells is sufficient for floral induction in Arabidopsis. Current Biology 17: 1055-1060.

Matsubara K, Yamanouchi U, Wang Z, Minobe Y, Izawa T, Yano M. 2008. Ehd2, a rice orthologue of the maize INDETERMINATE1 gene, promotes flowering by up-regulating Ehd1. Plant Physiology 148: 1425-1435.

Meng X, Muszynski M, Danilevskaya O. 2011. The FT-like ZCN8 gene functions as a floral activator and is involved in photoperiod sensitivity in maize. Plant Cell 23: 942-960.

Morgan P, Finlayson S. 2000. Physiology and genetics of maturity and height. In: Smith CW, Frederiksen RA, eds. Sorghum: origin, history, technology, and production. New York, NY, USA: John Wiley \& Sons, 240-242.
Murphy RL, Klein RR, Morishige DT, Brady JA, Rooney WL, Miller FR, Dugas DV, Klein PE, Mullet JE. 2011. Coincident light and clock regulation of pseudoresponse regulator protein 37 (PRR37) controls photoperiodic flowering in sorghum. Proceedings of the National Academy of Sciences, USA 108: 16469-16474.

Murphy RL, Morishige DT, Brady JA, Rooney WL, Yang S, Klein PE, Mullet JE. 2014. Ghd7 (Ma6) Represses flowering in long days: a key trait in energy sorghum hybrids. PLoS One 9: e105352.

Muszynski M, Dam T, Li B, Shirbroun D, Zea Hou. 2006. delayed flowering1 encodes a basic leucine zipper protein that mediates floral inductive signals at the shoot apex in maize. Plant Physiology 142: 1523-1536.

Olson S, Ritter K, Rooney W, Kemanian A, McCarl B, Zhang Y, Hall S, Packer D, Mullet J. 2012. High biomass yield energy sorghum: developing a genetic model for $\mathrm{C}_{4}$ grass bioenergy crops. Biofuels Bioproducts Biorefining 6: 640-655.

Park S, Kim S, Lee S, Je B, Piao H. 2008. Rice Indeterminate 1 (OsIdI) is necessary for the expression of Ehd1 (Early heading date 1) regardless of photoperiod. Plant Journal 56: 1018-1029.

Putterill J, Robson F, Lee K, Simon R, Coupland G. 1995. The CONSTANS gene of Arabidopsis promotes flowering and encodes a protein showing similarities to zinc finger transcription factors. Cell 80: 847-857.

Quinby J. 1966. Fourth maturity gene locus in sorghum. Crop Science 6: 516$\underline{518 .}$

Quinby J. 1973. The genetic control of flowering and growth in sorghum. Advances in Agronomy 25: 125-162.

Quinby J, Karper R. 1945. The inheritance of three genes that influence time of floral initiation and maturity date in milo. Agronomy Journal 37: 916-936.

Rooney W, Aydin S. 1999. Genetic control of a photoperiod-sensitive response in Sorghum bicolor (L.) Moench. Crop Science 39: 397-400.

Rooney W, Blumenthal J, Bean B, Mullet J. 2007. Designing sorghum as a dedicated bioenergy feedstock. Biofuels Bioproducts Biorefining 1: 147-157.

Samach A, Onouchi H, Gold SE, Ditta GS, Schwarz-Sommer Z, Yanofsky MF, Coupland G. 2000. Distinct roles of CONSTANS target genes in reproductive development of Arabidopsis. Science 288: 1613-1618.

Suárez-López P, Wheatley K, Robson F, Onouchi H, Valverde F, Coupland G. 2001. CONSTANS mediates between the circadian clock and the control of flowering in Arabidopsis. Nature 410: 1116-1120.

Tadege M, Lin H, Bedair M, Berbel A, Wen JQ, Rojas CM, Niu LF, Tang YH, Sumner L, Ratet $\mathrm{P}$ et al. 2011. STENOFOLIA regulates blade outgrowth and leaf vascular patterning in Medicago truncatula and Nicotiana sylvestris. Plant Cell 23: 2125-2142.

Tamaki S, Matsuo S, Wong HL, Yokoi S, Shimamoto K. 2007. Hd3a protein is a mobile flowering signal in rice. Science 316: 1033-1036.

Taoka K, Ohki I, Tsuji H, Furuita K, Hayashi K, Yanase T, Yamaguchi M, Nakashima C, Purwestri YA, Tamaki S. 2011. 14-3-3 proteins act as intracellular receptors for rice Hd3a florigen. Nature 476: 332-337.

Taoka K, Ohki I, Tsuji H, Kojima C, Shimamoto K. 2013. Structure and function of florigen and the receptor complex. Trends in Plant Science 18: 287294.

Thomasson JR, Nelson ME, Zakrzewski RJ. 1986. A fossil grass (gramineae, chloridoideae) from the miocene with kranz anatomy. Science 233: 876-878.

Turner A, Beales J, Faure S, Dunford R, Laurie D. 2005. The pseudoresponse regulator Ppd-H1 provides adaptation to photoperiod in barley. Science 310 : 1031-1034.

Valverde F, Mouradov A, Soppe W, Ravenscroft D, Samach A, Coupland G. 2004. Photoreceptor regulation of CONSTANS protein in photoperiodic flowering. Science 303: 1003-1006.

Vanderlip RL, Reeves HE. 1972. Growth stages of sorghum. Agronomy Journal 64: 13-17.

Wigge PA, Kim MC, Jaeger KE, Busch W, Schmid M, Lohmann JU, Weigel D. 2005. Integration of spatial and temporal information during floral induction in Arabidopsis. Science 309: 1056-1059.

Wu C, You C, Li C, Long T, Chen G. 2008. RID1, encoding a Cys2/His2-type zinc finger transcription factor, acts as a master switch from vegetative to floral development in rice. Proceedings of the National Academy of Sciences, USA 105: 12915-12920. 
Xue W, Xing Y, Weng X, Zhao Y, Tang W. 2008. Natural variation in Ghd7 is an important regulator of heading date and yield potential in rice. Nature Genetics 40: 761-767.

Yamaguchi A, Kobayashi Y, Goto K, Abe M, Araki T. 2005. TWIN SISTER OF $F T(T S F)$ acts as a floral pathway integrator redundantly with FT. Plant Cell Physiology 46: 1175-1189.

Yan L, Loukoianov A, Blechl A, Tranquilli G, Ramakrishna W. 2004. The wheat $V R N 2$ gene is a flowering repressor down-regulated by vernalization. Science 303: 1640-1644.

Yang S, Murphy R, Morishige D, Klein P, Rooney W. 2014b. Sorghum phytochrome B inhibits flowering in long days by activating expression of SbPRR37 and SbGHD7, repressors of SbEHD1, SbCN8 and SbCN12. PLoS ONE 9: e105352.

Yang S, Weers BD, Morishige DT, Mullet JE. 2014a. CONSTANS is a photoperiod regulated activator of flowering in sorghum. BMC Plant Biology 14: 148.

Zeevaart JA. 1976. Physiology of flower formation. Annual Review of Plant Physiology 27: 321-348.

Zeevaart JA. 2008. Leaf-produced floral signals. Current Opinion in Plant Biology 11: 541-547.

\section{Supporting Information}

Additional supporting information may be found in the online version of this article.

Fig. S1 Sequence alignment of SbFT/TFL1/MFT-like and related PEBP proteins.

Fig. S2 Expression levels of SbFT genes in the leaves of lateflowering sweet sorghum Rio and forage sorghum FS000504 (FS) under SD conditions.

Fig. S3 Flowering phenotypes of SbFT transgenic Arabidopsis lines.
Fig. S4 Overexpression of SbFT2, SbFT6 and SbFT9 genes in transgenic Arabidopsis Ler and $f t-1$ mutant plants does not alter flowering time.

Fig. S5 Yeast two-hybrid (Y2H) protein interaction assay of sorghum FT proteins with AtFD, SbFD1, and Sb14-3-3, and with each other.

Fig. S6 BiFC assay and localization of SbFT and Sb14-3-3 proteins.

Fig. S7 Induction of floral meristem identity marker genes, AtAP1 and AtLFYi, in SbFT-expressing transgenic Arabidopsis lines.

Table S1 Full-length amino acid sequence identity of sorghum PEBPs with maize and rice homologs

Table S2 Amino acid sequence identity within sorghum PEBP family proteins

Table S3 Lists of primers used in this study

Notes S1 Accession numbers or gene identifiers of sequences used in this study.

Please note: Wiley Blackwell are not responsible for the content or functionality of any supporting information supplied by the authors. Any queries (other than missing material) should be directed to the New Phytologist Central Office. 